\title{
AKIBAT HUKUM ATAS PEMBATALAN SURAT KEPUTUSAN BUPATI TENTANG PEMBERHENTIAN KEPALA DESA SUMURBER KECAMATAN PANCENG KABUPATEN GRESIK (Studi Putusan Nomor: 92/G/2013/PTUN.Sby)
}

\author{
Eksan $^{1}$, Ainul Masruroh ${ }^{2}$, Sholihan $^{3}$ \\ ${ }^{123}$ Universitas Islam Darul 'Ulum Lamongan \\ 1eksan91@gmail.com, ${ }^{2}$ ainul@unisda.ac.id, ${ }^{3}$ sholihan@unisda.ac.id
}

\begin{abstract}
The agency or the administrative office of the State does not necessarily succeed in carrying out its duties, sometimes the dispute arises due to a decision of the State administration that can cause dissatisfaction. The proposed termination of village chief conducted by the Village consultative Agency is not qualified as a reason to dismiss the head of Sumurber village, Panceng District, Gresik Regency. In addition to the State Administrative Decreelobject dispute is contrary to government regulation about the village, also contrary to the regional regulation of Gresik Regency number 12 Year 2006 about the village government. On the other hand, the country's administrative decisions are contrary to good principles of government. Because the State Administrative Decreelobject dispute is a state administrative decision contrary to good laws and principles of government. The author uses a method of scripting which provides the solution of legal case ATS that occur. This study analyzed the cancellation of decree of Regent of Gresik No. 141/678/HK/437.12/2013, dated 3 May 2013 concerning the dismissal of the village head of Sumurber, Panceng District, Gresik Regency. The decision of deliberation of the village consultative Agency related to the termination of the village head has been null and void, as a result of the Regent's decision on the termination of Sumurber village chief is irrevocable.
\end{abstract}

Keywords: Consequences of law, Cancellation, Regent, Head of village.

\begin{abstract}
ABSTRAK
Badan atau pejabat tata usaha negara tidak serta merta berhasil melaksanakan tugasnya, terkadang timbul sengketa yang ditimbulkan akibat adanya suatu keputusan tata usaha negara yang bisa menimbulkan ketidakpuasan. Usulan Pemberhentian Kepala Desa yang dilakukan oleh Badan Permusyawaratan Desa tidak memenuhi kualifikasi sebagai alasan dalam memberhentikan Kepala Desa Sumurber, Kecamatan Panceng, Kabupaten Gresik. Selain Keputusan Tata usaha Negara /objek sengketa tersebut bertentangan dengan Peraturan Pemerintah Tentang Desa, juga bertentangan dengan Peraturan Daerah Kabupaten Gresik Nomor 12 Tahun 2006 tentang Pemerintahan Desa. Disisi lain Keputusan Tata Usaha Negara Tersebut bertentangan dengan Asas-asas Pemerintahan yang baik. Karena Keputusan Tata Usaha Negara/objek sengketa merupakan Keputusan Tata Usaha Negara yang bertentangan dengan undang-undang dan asas pemeritahan yang baik. penulis menggunakan metode perskriptif yaitu memberikan solusi ats kasus hukum yang terjadi. Penelitian ini menganalisis Pembatalan Surat keputusan Bupati Gresik Nomor 141/678/HK/437.12/2013, Tanggal 3 Mei 2013 tentang
\end{abstract}


pemberhentian Kepala Desa Sumurber, Kecamatan Panceng, Kabupaten Gresik. Keputusan musyawarah Badan Permusyawaratan Desa terkait pemberhentian Kepala Desa telah batal demi hukum maka akibat hukum dari keputusan Bupati tentang pemberhentian Kepala Desa Sumurber adalah dapat dibatalkan.

\section{Kata Kunci: Akibat Hukum, Pembatalan, Bupati, Kepala Desa.}

\section{PENDAHULUAN}

Hukum acara yang dipergunakan pada Peradilan Tata Usaha Negara ialah Hukum Acara Peradilan Tata Usaha Negara yang bersumber dari Hukum Acara Perdata. Hukum Acara Peradilan Tata Usaha Negara adalah rangkaian peraturanperaturan yang memuat cara bagaimana orang harus bertindak terhadap dan di muka Pengadilan dan cara bagaimana Pengadilan itu harus bertindak, satu sama lain untuk melaksanakan berjalannya peraturan Hukum Tata Usaha Negara. Adakalanya aparat pemerintah dalam menyelenggarakan pemerintahan, membuat keputusan yang melampaui batas kewenangannya (detournement de pouvior) atau ada kekeliruan dalam menerapkan peraturan hukumnya saat menyelesaikan suatu masalah tertentu yang konkret (abus de droit), sehingga akibatnya ada masyarakat yang dirugikan oleh keputusannya itu. Maka Peradilan Tata Usaha Negara berfungsi sebagai badan tempat masyarakat mencari keadilan. ${ }^{1}$

Tata Usaha Negara adalah administrasi negara yang melaksanakan fungsi untuk menyelenggarakan urusan pemerintahan (kegiatan yang bersifat eksekutif) baik di pusat maupun di daerah. ${ }^{2}$ Dalam melaksanakan tugasnya badan atau pejabat tata usaha negara tidak serta merta berhasil melaksanakan tugasnya. Terkadang timbul sengketa yang ditimbulkan akibat adanya suatu keputusan tata usaha negara yang bisa menimbulkan ketidakpuasan. Sengketa disini bisa terjadi antara badan atau pejabat tersebut dengan masyarakat umum maupun antara badan atau pejabat dengan sesama anggota dari badan dan pejabat tata usaha negara itu sendiri.

Badan atau Pejabat Tata Usaha Negara adalah badan atau pejabat yang melaksanakan urusan pemerintahan berdasarkan peraturan perundang-undangan yang berlaku dan yang dimaksud Sengketa tata usaha negara adalah sengketa yang timbul dalam bidang tata usaha negara antara orang atau badan hukum perdata

1 Bachsan Mustafa, Sistem Hukum Administrasi Negara Indonesia,Citra Aditya Bakti, Bandung, 2001, h. 109

${ }^{2}$ Indroharto, Usaha Memahami Undang-Undang Tentang Peradilan Tata Usaha Negara, Pustaka Sinar Harapan, Jakarta, 2004, h. 27 
dengan badan atau pejabat tata usaha negara sebagai akibat dikeluarkannya suatu keputusan tata usaha negara yang dianggap melanggar hak.

Surat keputusan Bupati Gresik Nomor 141/678/HK/437.12/2013, Tanggal 3 Mei 2013 tentang pemberhentian Kepala Desa Sumurber, Kecamatan Panceng, Kabupaten Gresik, sebagaimana telah diumumkan dalam berita daerah Kabupaten Gresik, tanggal 3 Mei 2013, Nomor 811 (Keputusan Tata Usaha Negara/objek sengketa) menimbulkan masalah dalam penerbitan Keputusan Tata Usaha Negara. Kedudukanya sebagai Bupati Gresik yang telah menerbitkan Surat Keputusan Tata Usaha Negara/objek sengketa dapat dikualifikasikan sebagai Badan atau Pejabat Tata Usaha Negara Karena Merupakan Badan atau Pejabat yang melaksanakan urusan Pemerintahan berdasarkan peraturan perundang-undangan yang berlaku. dalam ketentuan pasal (1) ayat (2) Undang-undang Nomor 5 Tahun 1986 tentang Peradilan Tata Usaha Negara juncto pasal (1) angka (8) Undang-Undang nomor 51 Tahun 2009 Tentang Peradilan Tata Usaha Negara. Keputusan Tata Usaha Negara Tersebut adanya suatu pertentangan antara Keputusan Tata Usaha Negara/objek sengketa dengan peraturan perundang-undangan yang berlaku serta asas-asas pemerintahan yang baik yang mana Keputusan Tata Usaha Negara /objek sengketa bertentangan dengan pasal (17) ayat (4) Peraturan Pemerintah Nomor 72 Tahun 2005 tentang Desa.

Terbitnya Keputusan Tata Usaha Negara tersebut atas dasar pertimbangan surat camat Panceng Nomor 140/20/437.115/2013, tanggal 2 April 2013, adanya usulan Surat ketua Badan Permusyawaratan Desa (BPD) Desa Sumurber, Kecamatan Panceng, Kabupaten Gresik Nomor 05/BPD/IV/2013, Tanggal 02 April 2013, tentang usulan pemberhentian Kepala Desa Sumurber, dan Keputusan Badan Permusyawaratan Desa (BPD) Desa Sumurber Nomor 04 Tahun 2013 Tentang Usulan Pemberhentian Kepala Desa Sumurber. Usulan pemberhentian Kepala Desa Sumurber, Kecamatan Panceng, Kabupaten Gresik Tersebut adalah dilatarbelakangi adanya kekisruhan dalam Pemerintahan Desa Sumurber sebagai akibat adanya Tuduhan Perselingkuhan yang dilakukan oleh Kepala Desa dengan anggota masyarakat, sehingga kemudian Terjadi demonstrasi dan pendudukan Kantor Desa Sumurber oleh sebagian warga Desa Sumurber. ${ }^{3}$ Keputusan Tata Usaha

\footnotetext{
${ }^{3}$ Putusan Peradilan Tata Usaha Negara Nomor 92/G/2013/PTUN, Surabaya.
} 
Negara/Objek sengketa Tersebut bertentangan dengan Pasal (17) ayat (2) Huruf F Peraturan Pemerintah Nomor 72 Tahun 2005 Tentang Desa adapun alasan-alasan tersebut yakni

1. Tidak lagi memenuhi syarat Kepala Desa

2. Dinyatakan melanggar sumpah/janji jabatan

3. Tidak melaksanakan kewajiban sebagai Kepala Desa dan atau

4. Melanggar larangan bagi Kepala Desa.

Usulan Pemberhentian Kepala Desa yang dilakukan oleh Badan Permusyawaratan Desa tidak memenuhi kualifikasi sebagai alasan dalam memberhentikan Kepala Desa Sumurber, Kecamatan Panceng, Kabupaten Gresik. Selain Keputusan Tata usaha Negara /objek sengketa tersebut bertentangan dengan Peraturan Pemerintah Tentang Desa, juga bertentangan dengan Peraturan Daerah Kabupaten Gresik Nomor 12 Tahun 2006 tentang Pemerintahan Desa. Disisi lain Keputusan Tata Usaha Negara Tersebut bertentangan dengan Asas-asas Pemerintahan yang baik. Karena Keputusan Tata Usaha Negara/objek sengketa merupakan Keputusan Tata Usaha Negara yang bertentangan dengan undangundang dan asas pemeritahan yang baik. Dalam pasal (53) ayat (1) Undang-undang No. 5 Tahun 1986 menyatakan seseorang atau badan hukum perdata yang merasa kepentinganya dirugikan oleh suatu Keputusan Tata Usaha Negara dapat mengajukan gugatan tertulis kepada Pengadilan yang berwenang, yang berisi tuntutan agar Keputusan Tata Usaha Negara yang disengketakan itu dinyatakan batal atau tidak sah, dengan atau tanpa disertai tuntutan ganti rugi dan/atau rehabilitasi.

Kepala Desa Sumurber Kecamatan Panceng Kabupaten Gresik, merasa dirugikan akan kepentingannya dengan terbitnya Keputusan Tata Usaha Negara dalam hal ini Surat keputusan Bupati Gresik Nomor 141/678/HK/437.12/2013, Tanggal 3 Mei 2013 tentang pemberhentian Kepala Desa Sumurber, Kecamatan Panceng, Kabupaten Gresik, sebagaimana telah diumumkan dalam berita daerah Kabupaten Gresik, tanggal 3 Mei 2013, Nomor 811 (Keputusan Tata Usaha Negara/objek sengketa) yang bertentangan dengan Peraturan Perundang-undangan yang berlaku Sehingga Kepala Desa melakukan Pengajuan Gugatan pembatalan 
tentang Surat Keputusan Tata Usaha Negara Tersebut di Peradilan Tata Usaha Negara.

\section{METODE PENELITIAN}

Metode yang digunakan dalam peneltiian ini adalah mengikuti metode penelitian hukum normatif. Penelitian yuridis normatif adalah penelitian hukum yang meletakkan hukum sebagai sebuah bangunan sistem norma. Sistem norma yang dimaksud adalah mengenai asas-asas, norma, kaidah dari peraturan perundang-undangan, putusan pengadilan serta doktrin (ajaran). Sedangkan untuk metode penulisan penelitian ini, penulis menggunakan metode perskriptif yaitu memberikan solusi ats kasus hukum yang terjadi. Dalam penelitian ini penulis akan menganalisis Pembatalan Surat keputusan Bupati Gresik Nomor 141/678/HK/437.12/2013, Tanggal 3 Mei 2013 tentang pemberhentian Kepala Desa Sumurber, Kecamatan Panceng, Kabupaten Gresik.

\section{HASIL DAN PEMBAHASAN}

\section{Dasar Pengujian Keputusan Tata Usaha Negara}

Dasar gugatan yang diajukan penggugat adalah sama dengan dasar pengujian yang dilakukan oleh pengadilan lingkungan Peradilan Tata Usaha Negara terhadap Keputusan Tata Usaha Negara yang disengketakan. Dari ketentuan yang terdapat dalam pasal 53 ayat 2 Undang-Undang Nomor 09 Tahun 2004, dapat diketahui bahwa keputusan tata usaha negara akan dinyatakan batal atau tidak sah jika memenuhi kualifikasi sebagai berikut :

a) Keputusan tata usaha negara yang digugat bertentangan dengan Peraturan Perundang-undangan yang berlaku yaitu:

1. Bertentangan dengan ketentuan-ketentuan dalam peraturan perundangundangan yang bersifat prosedural/formal.

2. Bertentangan dengan ketentuan-ketentuan dalam peraturan perundangundangan yang bersifat materiil/ substansial.

3. Dikeluarkan oleh Badan atau Pejabat Tata Usaha Negara yang tidak berwenang.

b) Keputusan Tata Usaha Negara yang digugat bertentangan dengan asas-asas umum pemerintahan yang baik. 
Dalam Keputusan Tata Usaha Negara bertentangan dengan asas-asas umum pemerintahan yang baik yang diatur dalam Undang-undang Nomor 5 Tahun 1986 di ubah dengan Undang -undang Nomor 9 Tahun 2004, bentuk-bentuk dari asas umum pemerintahan yang baik adalah dalam bentuk tertulis, dan dalam bentuk tidak tertulis. asas umum pemerintahan yang baik dalam bentuk tertulis, dapat diketahui dari penjelasan pasal 53 ayat 2 huruf b yang menyebutkan bahwa yang dimaksud dengan asas umum pemerintahan yang baik adalah meliputi asas kepastian hukum, tertib penyelenggara negara, keterbukaan, proporsionalitas, profesionalitas, dan akuntabilitas.

Sedangkan Asas umum pemerintahan yang baik dalam bentuk tidak tertulis, oleh S.F. Marbun dikemukakan sebagai berikut yakni asas persamaan, asas keseimbangan, keserasian, dan keselarasan, asas menghormati dan memberikan haknya setiap orang, asas ganti rugi karena kesalahan, asas kecermatan, asas kepastian hukum, asas kejujuan dan keterbukaan, asas larangan penyalahgunaan wewenang, asas larangan sewenang-wenang, asas kepercayaan dan pengharapan, asas motifasi, asas kepantasan dan kewajaran, asas pertanggung jawaban, asas kepekaan, asas penyelenggaraan kepentingan umum, asas kebijaksanaan, dan asas iktikad baik. $^{4}$

\section{Kompetensi Badan atau Pejabat Tata Usaha Negara}

Badan atau Pejabat Tata Usaha Negara menjadi tergugat dalam sengketa Tata Usaha Negara, perlu terlebih dahulu diperhatikan jenis dari wewenang Badan atau Pejabat Tata Usaha Negara pada waktu mengeluarkan Keputusan Tata Usaha Negara, apakah atribusi pemberian kuasa (mandat) atau pelimpahan wewenang (delegasi) yang dimaksud dengan masing-masing jenis wewenang tersebut adalah

a. Wewenang yang diberikan dengan atribusi artinya wewenang yang langsung diberikan atau langsung ditentukan oleh peraturan perundang-undangan kepada Badan atau Pejabat Tata Usaha Negara.

b. Wewenang yang diberikan dengan mandat artinya wewenang yang diberikan kepada mandataris (penerima mandat) dari mandans (pemberi mandat) melaksanakan wewenang untuk dan atas nama mandans. hal $88-95$

${ }^{4}$ R.WIYONO, Hukum Acara Peradilan Tata Usaha Negara, Jakarta:Sinar Grafika,2010,cet.3, 
c. Wewenang yang diberikan dengan delegasi artinya wewenang yang diberikan dengan penyerahan wewenang dari delegans (pemberi delegasi) kepada delegataris (penerima delegasi).

Asas-asas Hukum Administrasi Yang Melandasi Hukum Acara Peradilan Administrasi Dalam Ketentuan Hukum Acara Peradilan Administrasi

Hukum Acara Peradilan Administrasi mempunyai karakteristik yang tercermin dalam Asas-asas hukum administrasi yang melandasi hukum acara peradilan administrasi yang menurut Van Galen dan Maarseveen sebagian besar berhubungan langsung dengan maksud beracara menurut hukum administrasi yang memberikan perlindungan hukum terhadap tindak pemerintahan, adapun Asas-asas tersebut adalah sebagai berikut:

1. Asas Praduga Rechtmatig (Vermoede Van Rechtmatigheid $=$ Praesumtio Iustae Causa)

Philipus M.Hadjon dalam bukunya pemerintahan menurut hukum (Wet-en Rechtmatig Bestuur) menyatakan: setiap tindakan pemerintahan selalu harus dianggap Rechmatig sampai ada pembatalanya. Tegasnya selama keputusan tersebut belum dinyatakan tidak sah dengan putusan pengadilan (dalam lingkungan peradilan administrasi) yang telah memperoleh kekuatan hukum tetap, keputusan itu dianggap sah dan mempunyai kekuatan hukum untuk berlaku.

Konsekuensi Asas Praduga tidak bersalah dalam Hukum Acara Peradilan Administrasi yakni Gugatan tidak menunda pelaksanaan keputusan organ pemerintahan yang digugat, Diperlukan adanya suatu acara singkat, Tidak dikenal adanya putusan sela seperti yang dikenal dalam hukum acara perdata sebagai provisionele vonnis sehingga tidak terdapat adanya pelaksanaan serta merta dari putusan akhir pengadilan, dan Keputusan organ pemerintahan hanya dapat dibatalkan (vernietigbaar) dan bukan batal demi hukum (van rechtswege nietig)

2. Asas Pembuktian Bebas (vrij bewijs)

Menurut Van Wijk dan Willem Konijnenbelt dalam asas pembuktian bebas terkandung makna hakim mempunyai kebebasan yang sangat besar dalam membagi beban pembuktian dan menerima serta menilai alat-alat bukti. Dengan berlandaskan pada asas pembuktian bebas, dalam hukum acara peradilan administrasi dalam melakukan pembuktian hakim tidak tergantung pada fakta yang dikemukakan para 
pihak. Hakim dapat melengkapi fakta diluar yang diajukan para pihak dalam pengambilan putusan, Hakim yang membagi beban pembuktian diantara para pihak; siapa yang diwajibkan untuk membuktikan dan tidak berhasil membuktikan mengandung risiko dikalahkan, dan dimungkinkannya penerapan beban pembuktian terbalik, Tidak dikehendaki adanya ketentuan yang mengikat hakim dalam memilih alat bukti. Dalam ukuran acara peradilan administrasi yang dipersoalkan ialah rechtmatigheid suatu keputusan organ pemerintahan, sehingga yang diperlukan ialah alat ukur dan bukanya alat bukti, dan Penilaian terhadap hasil pembuktian diserahkan sepenuhnya kepada hakim yang bersangkutan.

\section{Asas Keaktifan Hakim (Actieve Rechter $=$ Dominus Litis)}

Menurut J.A. Borman ada dua sikap hakim dalam mengadili suatu sengketa pertama, sangat formil. Hanya memperhatikan sebatas yang dikemukakan para pihak. mencari kebenaran formal; kedua aktif. Hakim berupaya mencari dan mengungkapkan fakta dan melengkapi segi hukum. Mencari kebenaran materiil. Sikap hakim admnistrasi adalah aktif. Sikap aktif tersebut dikarenakan mencari kebenaran atas peristiwa di muka peradilan administrasi merupakan kepentingan publik yang menurut hukum publik hakim harus diberi wewenang yang besar. Berdasarkan asas keaktifan hakim, dalam hukum acara peradilan administrasi bahwa Keaktifan selama proses pemeriksaan sengketa sepenuhnya terletak pada hakim. Tidak berlaku otonomi pihak-pihak yang bersengketa, Hakim berwenang mengadakan pemeriksaan persiapan untuk mengetahui kelengkapan gugatan. Pemeriksaan di persidangan harus dianggap gugatan telah sempurna, sehingga adanya amar putusan yang berupa gugatan tidak diterima tidak dibenarkan, Ultra petita tidak dilarang. Hakim dapat memutus lebih dari apa yang diminta, sehingga dimungkinkan adanya reformatio in peius, dan dalam melakukan pengujian keabsahan rechmatigheidstoetsing tehadap keputusan organ pemerintahan yang disengketakan, hakim tidak terikat pada alasan mengajukan gugatan yang dikemukakan oleh penggugat.

\section{Asas Erga Omnes}

Menurut Philipus M. Hadjon dalam karyanya berjudul beberapa catatan tentang hukum administrasi adalah putusan berlaku bagi semua orang. Maka dengan asas ini, putusan pengadilan dalam lingkungan peradilan administrasi 
berlaku bagi siapa saja dan bukan hanya mengikat para pihak yang bersengketa. Hal demikian itu merupakan pengejawentahan esensi peradilan administrasi yang pada dasarnya menegakkan hukum publik (hukum administrasi). ${ }^{5}$

\section{Akibat Hukum Dibatalkannya Keputusan Tata Usaha Negara Tentang Pemberhentian Kepala Desa Sumurber, Kecamatan Panceng, Kabupaten Gresik}

Keputusan Tata Usaha Negara Tentang Pemberhentian Kepala Desa Sumurber, Kecamatan Panceng, Kabupaten Gresik berakibat hukum pembatalan oleh pengadilan Tata Usaha Negara dengan duduk perkara sebagai berikut bahwa Penggugat adalah Kepala Desa Sumurber, terpilih berdasarkan pesta demokrasi yang telah dilangsungkan oleh warga Desa Sumurber Kecamatan Panceng Kabupaten Gresik pada tanggal 15 Maret 2008. penggugat menjabat Kepala Desa Sumurber Kecamatan Panceng Kabupaten Gresik selama 5 tahun dan 2 hari, secara tiba-tiba bersifat sewenang-wenang, serta tanpa alasan yang sah menurut hukum tergugat telah memberhentikan penggugat dengan menerbitkan Keputusan Bupati Gresik Nomor 141/678/HK/437.12/2013, Tanggal 3 Mei 2013 tentang pemberhentian Kepala Desa Sumurber, Kecamatan Panceng, Kabupaten Gresik, sebagaimana telah diumumkan dalam berita daerah Kabupaten Gresik, tanggal 3 Mei 2013, Nomor 811 (Keputusan Tata Usaha Negara/objek sengketa).

Kedudukanya sebagai Bupati Gresik yang telah menerbitkan Surat Keputusan Tata Usaha Negara/objek sengketa dapat dikualifikasikan sebagai Badan atau Pejabat Tata Usaha Negara karena merupakan Badan atau Pejabat yang melaksanakan urusan Pemerintahan berdasarkan peraturan perundang-undangan yang berlaku. Dalam terbitnya Keputusan Tata Usaha Negara Tersebut adanya suatu pertentangan antara Keputusan Tata Usaha Negara/objek sengketa dengan peraturan perundang-undangan yang berlaku serta asas-asas pemerintahan yang baik yang mana Keputusan Tata Usaha Negara /objek sengketa bertentangan dengan pasal 17 ayat 4 Peraturan Pemerintah Nomor 72 Tahun 2005 tentang Desa. Keputusan Tata Usaha Negara diterbitkan atas dasar pertimbangan surat camat Panceng Nomor 140/20/437.115/2013, tanggal 2 April 2013, tentang usul pemberhentian Kepala Desa, dan Surat ketua Badan Permusyawaratan Desa (BPD)

${ }^{5}$ Suparto Wijoyo, Karakteristik hukum acara peradilan administrasi, Airlangga University Press, Surabaya,1997, h. 54-75 
Desa Sumurber, Kecamatan Panceng, Kabupaten Gresik Nomor 05/BPD/IV/2013, Tanggal 02 April 2013, tentang usulan pemberhentian Kepala Desa Sumurber, sebagaimana Keputusan Badan Permusyawaratan Desa (BPD) Desa Sumurber Nomor 04 Tahun 2013 tentang Usulan Pemberhentian Kepala Desa Sumurber.

Usulan pemberhentian Kepala Desa Sumurber, Kecamatan Panceng, Kabupaten Gresik tersebut adalah dilatarbelakangi adanya kekisruhan dalam Pemerintahan Desa Sumurber. Sebagai akibat adanya tuduhan perselingkuhan yang dilakukan oleh Kepala Desa dengan anggota masyarakat yang bernama Hariyani, sehingga kemudian terjadi demonstrasi dan pendudukan Kantor Desa Sumurber oleh sebagian warga Desa Sumurber. dalam keputusan Tata Usaha Negara/Objek sengketa tersebut bertentangan dengan Pasal 17 ayat 2 Huruf C sampai F Peraturan Pemerintah Nomor 72 Tahun 2005 Tentang Desa adapun alasan-alasan tersebut adalah 1. Tidak lagi memenuhi syarat Kepala Desa 2. Dinyatakan melanggar sumpah/janji jabatan 3. Tidak melaksanakan kewajiban sebagai Kepala Desa dan atau 4. Melanggar larangan bagi Kepala Desa.

Usulan Pemberhentian Kepala Desa yang dilakukan oleh Badan Permusyawaratan Desa tidak memenuhi kualifikasi sebagai alasan dalam memberhentikan Kepala Desa Sumurber, Kecamatan Panceng, Kabupaten Gresik. Disamping itu Keputusan Tata usaha Negara /objek sengketa tersebut bertentangan dengan Peraturan Pemerintah Tentang Desa, juga melanggar Ketentuan pasal 36 ayat 1 dan 2 Peraturan Daerah Kabupaten Gresik Nomor 12 Tahun 2006 tentang Pemerintahan Desa. Karena Kepala Desa Sumurber Kecamatan Panceng Kabupaten Gresik, merasa dirugikan kepentinganya dengan terbitnya Keputusan Tata Usaha Negara dalam hal ini Surat keputusan Bupati Gresik, tentang pemberhentian Kepala Desa Sumurber, Kecamatan Panceng, Kabupaten Gresik, sebagaimana telah diumumkan dalam berita daerah Kabupaten Gresik, tanggal 3 Mei 2013, Nomor 811 (Keputusan Tata Usaha Negara/objek sengketa) yang bertentangan dengan Peraturan Perundang-undangan yang berlaku Sehingga Kepala Desa melakukan Pengajuan Gugatan pembatalan tentang Surat Keputusan Tata Usaha Negara Tersebut di Peradilan Tata Usaha Negara. 


\section{Alasan Pembatalan Keputusan Tata Usaha Negara}

Berdasarkan fakta hukum dengan melakukan pengujian terhadap penerbitan keputusan tata usaha negara dengan menggunakan alat uji berupa peraturan perundang-undangan yang terkait, khususnya mengenai tata cara pemberhentian kepala desa baik yang diatur dalam peraturan pemerintah maupun yang diatur dalam peraturan daerah dengan melakukan pengujian yaitu dari segi/aspek kewenangan, aspek formal prosedural maupun dari aspek substansi materiil sebagai berikut:

Adanya unsur kekurangan yuridis terhadap pembentukan keputusan berakibat pada keabsahan keputusan Tata Usaha Negara, yang memiliki pengaruh atau dampak mengenai kekuatan hukum berlakunya produk hukum oleh Badan atau Pejabat Tata Usaha Negara. Kekurangan yuridis tersebut salah satunya disebabkan adanya paksaan terhadap pembentukan Keputusan Tata Usaha Negara. Akibat hukumnya adalah Keputusan tersebut dapat dibatalkan. Bahwa suatu keputusan dinyatakan batal apabila unsur esensial yang ada dalam keputusan tersebut sebagai kehendak sipembuat secara nyata bertentangan dengan peraturan perundangundangan dan berbeda dengan kejadian sebenarnya.

Dalam norma Peraturan Daerah Kabupaten Gresik nomor 12 tahun 2006 tentang pemerintahan desa, Bupati Gresik berwenang untuk menerbitkan surat Keputusan Tata Usaha Negara. Menimbang, terkait dengan prosedur pemberhentian Kepala Desa menerapkan norma yang diatur dalam Peraturan Pemerintah nomor 72 Tahun 2005 tentang Desa jo. Peraturan Daerah Kabupaten Gresik nomor 12 Tahun 2006 tentang Desa jo. Peraturan Daerah Kabupaten Gresik nomor 3 Tahun 2010 tentang Badan Permusyawaratan Desa. Berdasarkan fakta persidangan rapat Badan Permusyawaratan Desa terkait dengan pengusulan pemberhentian Kepala Desa Sumurber dilakukan di balai Desa dengan diikuti dan dengan ancaman serta tekanan dari para pendemo yang menginginkan pemberhentian Kepala Desa terhadap Badan Permusyawaratan Desa yang hadir saat itu.

Hal ini membuktikan bahwa rapat Badan Permusyawaratan Desa dalam mengambil keputusan dalam rangka usulan pemberhentian Kepala Desa Sumurber adalah dilakkan secara terbuka. Sehingga dengan demikian secara formal prosedural proses pengambilan keputusan Badan Permusyawaratan Desa untuk 
usulan pemberhentian Kepala Desa adalah cacat hukum dari aspek formal prosedural karena rapat Badan Permusyawaratan Desa tidak dilakukan secara tertutup. Berdasarkan alasan tersebut diatas dapat disimpulankan penerbitan keputusan tata usaha negara ditinjau dari segi atau aspek formal prosedural adalah bertentangan dengan peraturan perundang-undangan yang berlaku.

Keputusan Tata Usaha Negara dikaji dari aspek substansi, terkait dengan alasan yang dijadikan dasar usulan pemberhentian Kepala Desa, dengan menggunakan pendekatan logika berfikir yang sebaliknya (acontrario) seharusnya Bupati Gresik dapat menolak pengesahan usulan pemberhentian Badan Permusyawaratan Desa terkait Pemberhentian Kepala Desa Sumurber oleh karena terhadap tuduhan atau anggapan warga yang mencurigai adanya tindakan asusila yang dilakukan Kepala Desa hanya dengan mendasarkan pada pemberitaan di media massa, bukan didasarkan atas putusan pengadilan yang telah memperoleh kekuatan hukum tetap sehingga dengan demikian penerbitan Keputusan Tata Usaha Negara selain terbukti bertentangan dengan peraturan perundang-undangan yang berlaku juga telah melanggar asas motifasi sebagaimana pasal 53 ayat 2 Huruf a dan b Undang-undang Nomor 9 Tahun 2004 tentang perubahan Undang-undang Nomor 5 Tahun 1986 tentang Peradilan Tata Usaha Negara.

Keputusan Badan Permusyawaratan Desa Sumurber yang merekomendasikan atau mengusulkan pemberhentian Kepala Desa Sumurber dimana dalam proses pengambilan keputusan Badan Permusyawaratan Desa terdapat adanya kekurangan yuridis berupa adanya cacad kehendak dalam hal pengambilan putusan yang dilakukan oleh Badan Permusyawaratan Desa disebabkan karena adanya paksaan dari para pengunjuk rasa yang menginginkan pemberhentian sebagai Kepala Desa Sumurber.

Akibat hukum dari keputusan Badan Permusyawaratan Desa Sumurber bagi hukum akibatnya dianggap tidak pernah ada maka dengan demikian Keputusan Bupati Gresik Nomor 141/678/HK/437.12/2013 tanggal 03 Mei 2013 tentang pemberhentian Kepala Desa Sumurber Kecamatan Panceng Kabupaten Gresik yang notabene merupakan pengesahan terhadap usul pemberhentian Kepala Desa Sumurber yang diusulkan oleh Pimpinan Badan Permusyawaratan Desa kepada Bupati melalui Camat berdasarkan keputusan musyawarah Badan Permusyawaratan 
Desa. Karena keputusan musyawarah Badan Permusyawaratan Desa terkait pemberhentian Kepala Desa telah batal demi hukum maka keputusan Bupati tentang pemberhentian Kepala Desa Sumurber adalah dapat dibatalkan artinya bagi hukum keputusan yang dibuat Bupati tersebut dan akibatnya ada sampai waktu pembatalan oleh Hakim atau oleh suatu badan pemerintah lain yang berwenang.

Penerbitan Keputusan Tata Usaha Negara adalah telah bertentangan dengan peraturan perundang-undangan yang berlaku dari aspek formal prosedural maupun dari aspek substansi materiil sehingga dapat disimpulkan Pengadilan menyatakan batal dan memerintahkan Bupati Gresik Untuk mencabut Keputusan Tata Usaha Negara dan Bupati Gresik menerbitkan Surat Keputusan Tata Usaha Negara yang baru dan merehabilitasi kedudukan Kepala Desa Sumurber pada posisi semula sebagai Kepala Desa Sumurber Kecamatan Panceng Kabupaten Gresik.

Keputusan Tata Usaha Negara tentang pemberhentian Kepala Desa Sumurber Kecamatan Panceng Kabupaten Gresik secara yuridis Keputusan Tata Usaha Negera tersebut bertentangan dengan ketentuan-ketentuan dalam peraturan perundang-undangan yang bersifat prosedural/formal dan bertentangan dengan ketentuan-ketentuan dalam peraturan perundang-undangan yang bersifat materiil/ substansial disisi lain Keputusan Tata Usaha Negara tentang pemberhentian Kepala Desa Sumurber Kecamatan Panceng Kabupaten Gresik tersebut bertentangan asasasas umum pemerintahan yang baik.

Sebagaimana ketentuan pasal 53 ayat (2) Huruf a dan b Undang-Undang Nomor 09 Tahun 2004 tentang Perubahan atas Undang-Undang Nomor 5 Tahun 1986. Sehingga Pembatalan Keputusan Tata Usaha Negara tentang Pemberhentian Kepala Desa Sumurber Kecamatan Panceng Kabupaten Gresik telah sesuai dengan teori Hukum Administrasi Negara dan Ketentuan Undang-Undang tentang Peradilan Tata Usaha Negara.

\section{KESIMPULAN}

Penerbitan Keputusan Tata Usaha Negara ditinjau dari segi atau aspek formal prosedural adalah bertentangan dengan peraturan perundang-undangan yang berlaku. terkait dengan alasan yang dijadikan dasar usulan pemberhentian Kepala Desa, dengan menggunakan pendekatan logika berfikir yang sebaliknya (acontrario). seharusnya Bupati Gresik dapat menolak pengesahan usulan 
pemberhentian Badan Permusyawaratan Desa terkait Pemberhentian Kepala Desa Sumurber oleh karena terhadap tuduhan atau anggapan warga yang mencurigai adanya tindakan asusila yang dilakukan Kepala Desa hanya dengan mendasarkan pada pemberitaan di media massa, bukan didasarkan atas putusan pengadilan yang telah memperoleh kekuatan hukum tetap sehingga dengan demikian penerbitan Keputusan Tata Usaha Negara selain terbukti bertentangan dengan peraturan perundang-undangan yang berlaku juga telah melanggar asas motifasi sebagaimana pasal (53) ayat (2) Huruf a dan b Undang-undang Nomor 9 Tahun 2004 tentang perubahan Undang-Undang Nomor 5 Tahun 1986 tentang Peradilan Tata Usaha Negara.

Penerbitan Keputusan Tata Usaha Negara adalah telah bertentangan dengan peraturan perundang-undangan yang berlaku dari aspek formal prosedural maupun dari aspek substansi materiil sehingga pengadilan menyatakan batal dan memerintahkan Bupati Gresik Untuk mencabut Keputusan Tata Usaha Negara agar Bupati Gresik menerbitkan Surat Keputusan Tata Usaha Negara yang baru dan merehabilitasi kedudukan Kepala Desa Sumurber pada posisi semula sebagai Kepala Desa Sumurber Kecamatan Panceng Kabupaten Gresik.

\section{DAFTAR BACAAN}

Hadjon, Philipus M., Pengantar Hukum Administrasi Negara, Gadjah Mada University Press, Yogyakarta, 1997.

Indroharto, Usaha Memahami Undang-Undang Tentang Peradilan Tata Usaha Negara, Pustaka Sinar Harapan, Jakarta, 2004.

Marbun, S.F., Peradilan Administrasi dan Upaya Administratif di Indonesia, Liberty, Yogjakarta, 1997.

Mustafa, Bachsan, Sistem Hukum Administrasi Negara Indonesia, Citra Aditya Bakti, Bandung, 2001.

R.Wiyono, Hukum Acara Peradilan Tata Usaha Negara, Sinar Grafika, Jakarta, 2010.

Soemitro, Rochmat, Peradilan Tata Usaha Negara, Eresco, Bandung, 1995.

Wijoyo, Suparto, Karakteristik hukum acara peradilan administrasi, Airlangga University Press, Surabaya, 1997. 